\title{
THE PHOSPHATIDES OF HUMAN PLASMA. I. NORMAL VALUES DETERMINED BY PAPER AND COLUMN CHROMATOGRAPHY
}

\author{
By WILLIAM H. R. NYE,* CHRISTINE WATERHOUSE AND \\ GUIDO V. MARINETTI \\ (From the Departments of Medicine and Biochemistry, University of Rochester School of \\ Medicine and Dentistry, Rochester, N. Y.)
}

(Submitted for publication October 4, 1960 ; accepted March 9, 1961)

Investigation of the phosphatides of human plasma has been, in the past, restricted by the inadequacies of the chemical methods available. The development of silicic acid column chromatography as a tool for phosphatide analysis by Lea, Rhodes and Stoll in 1955 (1) led to rapid advances in phosphatide biochemistry. This method was applied to the analysis of the phosphatides of human serum by Phillips in 1957 (2), and has since been used by him (3-5). Others have more recently applied modified column techniques to the analysis of human serum (6-11). The technique has been particularly helpful in investigations using radioactive isotopes, since relatively large amounts of lipid may be separated $(12,13)$.

While column chromatography is well suited to preparative work, quantitative paper chromatography, introduced in 1957 by Marinetti, Erbland and Kochen (14), gives greater resolving power and thus was particularly useful in our investigation of plasma phosphatides which was begun in 1958. The purpose of this paper is to present our findings in normal subjects, using quantitative paper chromatography, and to discuss certain facets of the phosphatide analysis of plasma brought to light by the combined use of column and paper chromatography.

\section{METHODS}

Young volunteers in apparent good health served as normal subjects. Blood samples, unless otherwise noted, were drawn in the fasting state. Venous blood was placed in a collecting bottle containing potassium oxalate.

Extraction of lipids from plasma. The method of Marinetti and co-workers $(14,15)$ was used for the extraction of lipids and for the quantitative paper and column chromatography of the phosphatides. Extrac-

* This investigation was begun during tenure of a Postdoctoral Training Fellowship in Biochemistry and continued during a Postdoctoral Research Fellowship, both from the National Heart Institute. tion of lipids from fresh plasma was carried out four times with a total of 15 vol of methanol-chloroform 1:1 ( $\mathrm{vol} / \mathrm{vol}$ ), the extraction mixture being raised to $60^{\circ} \mathrm{C}$ for 2 minutes each time. The extract was dried with a rotary vacuum evaporator with the aid of benzene. The lipid was re-extracted with chloroform, leaving behind a small amount of water-soluble residue. The chloroform solution of lipid was diluted to $10 \mathrm{ml}$, and triplicate 1$\mathrm{ml}$ aliquots were taken for the determination of total chloroform-soluble phosphorus, by the method of Harris and Popat (16), as modified by Marinetti, Erbland, A1brecht and Stotz (17). The remainder of the sample was dried, weighed, and dissolved in isoamyl alcoholbenzene $1: 1$ ( $\mathrm{vol} / \mathrm{vol}$ ) to give an approximate concentration of 5 to $10 \mu \mathrm{g}$ phosphorus per $10 \mu \mathrm{l}$ solvent.

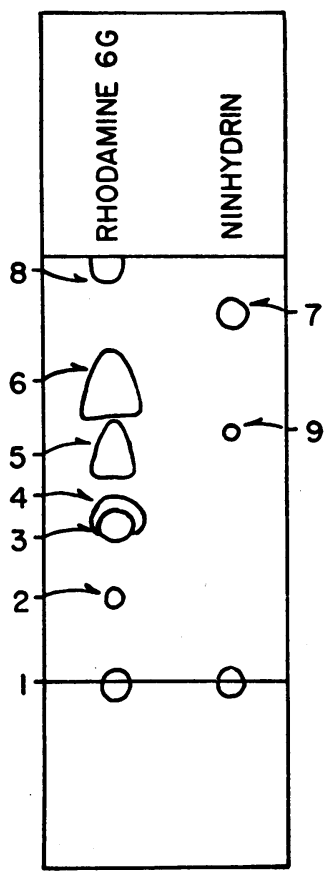

Fig. 1. Paper chromatogram of lipid extract of WhOle Plasma. 1, Origin. 2, Blue spot of unknown nature. 3, Lysolecithin. 4, Inositol phosphatide. 5, Sphingomyelin. 6, Lecithin. 7, Phosphatidylethanolamine. 8, Nonphosphatides. 9, Probably lysophosphatidylethanolamine. 
PHOSPHATIDES OF NORMAL HUMAN PLASMA

TABLE I

Data on optical density measurements

\begin{tabular}{|c|c|c|c|c|}
\hline & Lysolecithin & Sphingomyelin & Lecithin & $\begin{array}{l}\text { Phosphatidyl- } \\
\text { ethanolamine }\end{array}$ \\
\hline \multicolumn{5}{|c|}{ Optical density of blanks } \\
\hline Range & $\begin{array}{c}0.004-0.013 \\
\text { (one was } 0.019 \text { ) }\end{array}$ & $0.005-0.015$ & $\begin{array}{c}0.008-0.016 \\
\text { (one was } 0.028 \text { ) }\end{array}$ & $0.014-0.023$ \\
\hline Average & 0.009 & 0.009 & 0.014 & 0.018 \\
\hline No. determined & 15 & 14 & 11 & 8 \\
\hline \multicolumn{5}{|c|}{ Optical density obtained in representative analyses of normal subjects } \\
\hline Subject & & & & \\
\hline $\begin{array}{l}\text { J.N. } \\
\text { J.C. } \\
\text { J.P. } \\
\text { C.P. } \\
\text { D.S. }\end{array}$ & $\begin{array}{r}0.059 \\
.056 \\
.077 \\
.073 \\
.075 \\
.077 \\
.057 \\
.058 \\
.066 \\
.058\end{array}$ & $\begin{array}{r}0.158 \\
.153 \\
.144 \\
.152 \\
.145 \\
.128 \\
.145 \\
.143 \\
.138 \\
.130\end{array}$ & $\begin{array}{r}0.529 \\
.519 \\
.481 \\
.478 \\
.541 \\
.542 \\
.502 \\
.510 \\
.476 \\
.482\end{array}$ & \\
\hline
\end{tabular}

Isoamyl alcohol-benezene dissolved virtually all the lipid, leaving behind 0.03 to 0.8 per cent of the phosphorus.

Paper chromatography. Ten- $\mu$ l aliquots of isoamyl alcohol-benzene solution were pipetted onto silicic acidimpregnated paper. The chromatogram was developed in diisobutylketone-acetic acid-water 40:23:4 (vol) at $28^{\circ} \mathrm{C}$ for 16 hours; the paper was stained with a solution of rhodamine $6 \mathrm{G}$, and the lipid components were detected under ultraviolet light and were outlined in pencil. In Figure 1, a drawing of a paper chromatogram of a lipid extract of plasma is presented. The areas of paper containing lysolecithin, sphingomyelin, and lecithin, detected under ultraviolet light, and the area containing phosphatidylethanolamine, detected by a ninhydrin test, were carefully cut out, and the phosphorus was eluted with $1 \mathrm{~N} \mathrm{HCl}$ in redistilled methanol. After elution of the lipid phosphorus from each spot, quantitative transfer of the eluate through a fritted glass filter to a flask, evaporation of the solvent, and digestion with perchloric and nitric acids, the phosphorus was determined by the method of Chen, Toribara and Warner (18), and was read in a Beckman DU spectrophotometer at $820 \mathrm{~m} \mu$. Duplicate reagent blanks and standards containing known amounts of inorganic phosphate were prepared each time in large test tubes without digestion, after initially determining that readings identical with those of blanks and standards carried through the digestion procedure could be obtained by this method.

All glassware used in this procedure was cleaned in either hot sulfuric-nitric acids or in cold acid dichromate.
All reagents were of analytical grade and were used as obtained from the manufacturers, with the exception of the methanol used for phosphorus elution, which was redistilled. At the beginning of the investigation, blanks were prepared from areas of paper that were equivalent in size and position to each respective phosphatide spot. These blank areas were carried through the chromatographic development, staining, elution and phosphorus determination steps, and the average blank value for each constituent was determined. The optical density readings of the blanks and of representative phosphatide analyses that were obtained are shown in Table I. The two values for optical density obtained for each phosphatide component by duplicate chromatographic analysis were averaged, and the average blank value for that component was subtracted, giving the phosphorus in that phosphatide per $10 \mu 1$ isoamyl alcohol-benzene solution of lipid sample. Two other 10- $\mu 1$ samples were pipetted onto $1 \times 1$-inch Whatman no. 44 paper, digested directly, and analyzed for total phosphorus. The total phosphorus per 10- $\mu$ l aliquot was then related to the chloroform-soluble phosphorus per milliliter plasma (previously determined on triplicate aliquots of the chloroform re-extract of plasma) to determine the fraction of phosphorus in $1 \mathrm{ml}$ plasma that was present in $10 \mu 1$ of the isoamyl alcohol-benzene solution. When this fraction, which was usually between 0.1 and 0.05 , was then divided into the phosphorus in each phosphatide per $10-\mu 1$ aliquot, the value for phosphorus in that phosphatide per milliliter plasma was obtained:

$\mathrm{P}$ in phosphatide spot $/ \frac{\text { total } \mathrm{P} / 10 \mu \mathrm{l} \text { isoamyl alcohol-benzene }}{\text { chloroform-soluble } \mathrm{P} / \mathrm{ml} \text { plasma }} \equiv \mathrm{P}$ in phosphatide $/ \mathrm{ml}$ plasma. 


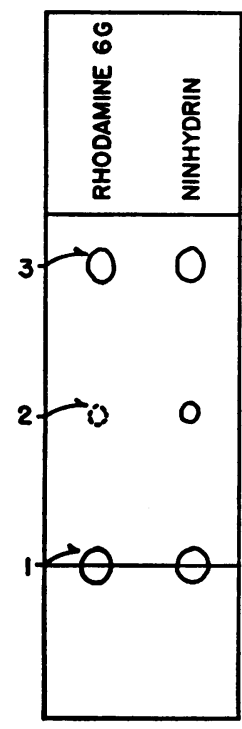

FR I



FR2

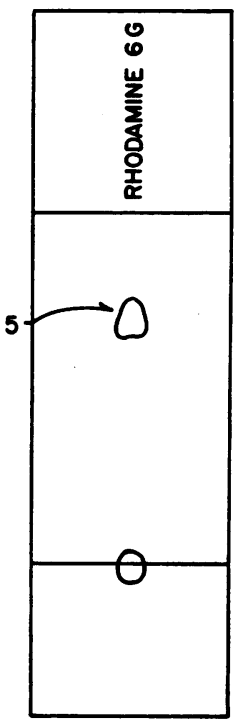

FR3



FR4

Fig. 2. PAPER Chromatograms of COLUMN FRACTIONS OF Lipid EXTRACT OF WHOLE plasma. 1, Origin. 2, Probably lysophosphatidylethanolamine. 3, Phosphatidylethanolamine. 4, Inositol phosphatide. 5, Lecithin. 6, Sphingomyelin. 7, Lysolecithin.

The recovery of phosphatides from the paper chromatogram was shown by two means to be quantitative: 1) complete recovery of phosphorus was obtained by eluting samples of lipid placed on small squares of silicic acidimpregnated paper; 2) red cell lipids were extracted and were separated by the method of column chromatography described below. Then fraction 3 , containing lecithin and a small percentage of sphingomyelin, was analyzed by quantitative paper chromatography. Fraction 4, containing sphingomyelin predominantly, was analyzed after ridding it of traces of lecithin and lysolecithin by mild alkaline hydrolysis, according to Dawson (19); 98.6 and 96.5 per cent of the phosphorus of fractions 3 and 4 applied to the paper chromatogram were recovered as phosphatide phosphorus, and 0.9 and 1.4 per cent of the phosphorus remained at the origin.

Column chromatography. The method for column chromatography described by Marinetti and colleagues (14), which is a modification of the method of Lea and co-workers (1), was used. The lipid extracted from $9 \mathrm{ml}$ plasma was placed on a column containing $10 \mathrm{~g}$ silicic acid. (Mallinckrodt AR 100 mesh). Nonphosphatides were removed with chloroform. Four phosphatide-containing fractions were eluted with the following solvents: 1) $95 \mathrm{ml} 20$ per cent methanol in chloroform ( vol/vol) ; 2) $95 \mathrm{ml} 30$ per cent methanol in chloroform; 3) $150 \mathrm{ml} 50$ per cent methanol in chloroform; 4) $125 \mathrm{ml}$ absolute methanol. The phosphorus in each fraction was determined, and a quantitative paper chromatographic analysis was carried out on each fraction. Figure 2 depicts drawings of paper chromatograms of the four fractions.

\section{RESULTS}

Quantitative analysis of the phosphatides by $p a$ per chromatography. In each paper chromatogram the areas containing lysolecithin, sphingomyelin, lecithin, and phosphatidylethanolamine were analyzed for phosphorus. The first three phosphatides contained most of the phosphorus and were considered to be the major components of the plasma phosphatide group. The amount of phosphorus contained in phosphatidylethanolamine has given an optical density from 0.015 to 0.056 in 61 determinations. Table I shows that these values are not far above the phosphorus blank for the area of paper occupied by phosphatidylethanolamine. Since the value calculated for phosphatidylethanolamine on the basis of paper chromatographic analysis alone may therefore be subject to a large error, it has not been used in calculating either the amount of the chloroformsoluble phosphorus accounted for as phosphatide, or the percentage composition of the phosphatides. Besides phosphatidylethanolamine, two other minor phosphatides have been found. A substance tentatively identified as inositol phosphatide has been detected in every sample. It overlaps the lysolecithin spot to some extent (see Figure 1). 
The value determined for lysolecithin can be expected to be slightly high by that amount of inositol phosphatide included in the lysolecithin area. A faint spot can often be detected by a ninhydrin test in the sphingomyelin area, probably representing lysophosphatidylethanolamine. The three minor components-phosphatidylethanolamine, inositol phosphatide, and lysophosphatidylethanolamine -have been separated and quantitated by the combined column and paper analysis (see Table IV). The errors introduced by the exclusion of phosphatidylethanolamine and part of the inositol phosphatide from the calculations, and by the incomplete chromatographic resolution of inositol phosphatide and lysophosphatidylethanolamine from the major phosphatides, can be seen to be of small magnitude.

Values obtained from the paper chromatographic analyses of plasma from normal subjects are listed in Table II. These values are expressed both in terms of the amount of phosphorus in each constituent and the percentage of phosphorus in each constituent relative to the sum of the phosphorus in the three constituents measured. It is seen that levels of chloroform-soluble phosphorus and of phosphorus in each constituent vary considerably from one sample to the next even when the samples have been obtained serially from the same subject, but that the percentage distribution of the phosphatide components varies much less. The chloroform-soluble phosphorus is also seen to rise after a meal, as does each phosphatide, but the relationships of the individual phosphatides to each other change m: ch less.

Quantitative analysis by a combination of column and paper chromatography. Thirteen plasmas from normal persons and from patients with various disease states (five from normal subjects, three from a patient with pulmonary disease, five from patients with nephrosis) have been analyzed by a combination of column and paper chromatography.

Figure 2 shows drawings of paper chromatograms of the four fractions collected by column chromatography. Column fraction 1, by paper chromatography, contained phosphatidylethanolamine and a small amount of a substance that was ninhydrin-positive and had the mobility and stain-

TABLE II

Data on paper chromatographic analyses of plasma from normal subjects

\begin{tabular}{|c|c|c|c|c|c|c|c|c|c|}
\hline \multirow[b]{2}{*}{ Subject } & \multirow[b]{2}{*}{$\begin{array}{l}\text { Chloroform- } \\
\text { soluble P }\end{array}$} & \multirow[b]{2}{*}{$\begin{array}{l}\text { Lyso- } \\
\text { lecithin }\end{array}$} & \multirow[b]{2}{*}{$\begin{array}{l}\text { Sphingo- } \\
\text { myelin }\end{array}$} & \multirow[b]{2}{*}{ Lecithin } & \multicolumn{3}{|c|}{ Phosphatide $\mathrm{P}$ in } & \multirow[b]{2}{*}{$\begin{array}{l}\text { Phosphatide } \\
\mathrm{P}^{*}\end{array}$} & \multirow{2}{*}{$\begin{array}{c}\text { Chloroform- } \\
\text { soluble P in } \\
\text { phosphatides }\end{array}$} \\
\hline & & & & & $\begin{array}{c}\text { Lyso- } \\
\text { lecithin }\end{array}$ & $\begin{array}{l}\text { Sphingo- } \\
\text { myelin }\end{array}$ & Lecithin & & \\
\hline & $\mu g / m l$ & & $\mu g P / m l$ plas & & $\%$ & $\%$ & $\%$ & $\mu g P / m l$ plasma & $\%$ \\
\hline J.N. & 98.7 & 5.4 & 16.3 & 56.6 & 6.9 & 20.8 & 72.2 & 78.3 & 79 \\
\hline J.C. & 123 & 9.5 & 19.9 & 66.7 & 9.9 & 20.7 & 69.4 & 96.1 & 78.2 \\
\hline J.P. & 88.6 & 6.5 & 12.4 & 51.5 & 9.2 & 17.6 & 73.2 & 70.4 & 79 \\
\hline C.P. & 114 & 7.0 & 18.5 & 67.4 & 7.6 & 19.9 & 72.5 & 92.9 & 81 \\
\hline D.S. & 123 & 7.6 & 17.8 & 66.0 & 8.3 & 19.5 & 72.2 & 91.5 & 74 \\
\hline $\begin{array}{l}\text { G.S. } \\
\text { W.N. }\end{array}$ & 58.6 & 5.2 & 11.6 & 30.9 & 9.9 & 22.3 & 67.8 & 47.7 & 81 \\
\hline \multicolumn{10}{|l|}{ Date } \\
\hline $9 / 5 / 58$ & 104 & 5.6 & 19.0 & 53.6 & 7.1 & 24.3 & 68.5 & 78.2 & 75 \\
\hline $9 / 8 / 58$ & 118 & 7.3 & 19.3 & 60.3 & 8.4 & 22.2 & 69.4 & 86.9 & 74 \\
\hline $9 / 11 / 58$ & 118 & 7.8 & 20.2 & 71.7 & 7.8 & 20.3 & 71.9 & 99.7 & 85 \\
\hline $9 / 15 / 58$ & 123 & 9.2 & 20.6 & 60.1 & 10.3 & 22.9 & 66.8 & 89.9 & 73 \\
\hline $9 / 19 / 58$ & 112 & 7.1 & 17.7 & 67.0 & 7.8 & 19.2 & 73.0 & 91.8 & 82 \\
\hline $1 / 26 / 59$ & 67.9 & 7.0 & 14.5 & 38.3 & 11.7 & 24.3 & 64.0 & 59.8 & 88 \\
\hline \multicolumn{10}{|l|}{ Fasting $\ddagger$} \\
\hline & & & 18.2 & 43.0 & 14.0 & 25.6 & 60.4 & 71.2 & 84 \\
\hline$+4 \mathrm{hrs}$ & 94 & 9.1 & 19.9 & 55.0 & 10.8 & 23.7 & 65.5 & 84.0 & 89 \\
\hline$+6.5 \mathrm{hrs}$ & & 9.6 & 22.2 & 63.5 & 10.1 & 23.3 & 66.6 & 95.3 & 99 \\
\hline $1 / 25 / 60$ & 94.3 & 6.7 & 15.5 & 53.0 & 8.8 & 20.3 & 70.9 & 75.2 & 80 \\
\hline
\end{tabular}

* Phosphatide phosphorus is the sum of the phosphorus in lysolecithin, sphingomyelin, and lecithin per ml plasma. $\dagger$ Per cent chloroform-soluble phosphorus in phosphatides $=\frac{\text { phosphatide } \mathrm{P}}{\text { chloroform-soluble } \mathrm{P}} \times 100$.

$\ddagger$ Time-interval after a breakfast of 2 eggs, butter, 2 slices toast and black coffee with sugar. 
TABLE III

Percentage of total phosphorus of each column fraction identified as phosphatide phosphorus

\begin{tabular}{lcccccc}
\hline \hline & \multicolumn{4}{c}{$\begin{array}{c}\text { Chloro- } \\
\text { form- }\end{array}$} & \multicolumn{4}{c}{$\begin{array}{c}\text { Total phosphorus recovered } \\
\text { as phosphatide }\end{array}$} & \begin{tabular}{c} 
Recovery of \\
P from \\
\cline { 3 - 6 } soluble
\end{tabular} & Frac. 1 & Frac. 2 & Frac. 3 & Frac. 4 & $\begin{array}{c}\text { folumn } \\
\text { Patient }\end{array}$ \\
\hline & $\begin{array}{c}P / m l \\
\text { plasma }\end{array}$ & $\%$ & $\%$ & $\%$ & $\%$ & $\%$ \\
L.C. & 88 & 23 & 49 & 65 & 68 & 106 \\
J.H. & 51 & 37 & 54 & 61 & 71 & 83 \\
E.J. & 63 & 43 & 19 & 81 & 77 & 93 \\
J.F. & 37 & 55 & 27 & 88 & 71 & 98 \\
& & 52 & & 97 & 79 & 89 \\
\hline
\end{tabular}

ing characteristics with rhodamine 6G of lysophosphatidylethanolamine. No phosphatidylserine was found. Fraction 2 contained a spot which had the mobility of inositol phosphatide. Fraction 3 contained lecithin and fraction 4 contained sphingomyelin and lysolecithin. The resolution between fractions 3 and 4 was never perfect. Usually, a small amount of lecithin appeared in fraction 4, and occasionally a small quantity of sphingomyelin appeared in fraction 3 . The total amount of each constituent, however, was determined from the quantitative paper chromatographic analyses of the column fractions.

The percentage of the total phosphorus of each fraction, which is identified as phosphatide phosphorus, is listed in Table III, and will be commented upon in the discussion. Table IV shows the data from representative analyses performed on both normal and abnormal plasmas by paper chromatography alone, and by a combination of column and paper chromatography. The results obtained by these two methods show no consistent differences except for the lower values for lysolecithin obtained by the latter method, which will receive comment in the discussion. Table IV shows the minor contribution that inositol phosphatide, phosphatidylethanolamine, and lysophosphatidylethanolamine make to the phosphatide analysis because of their low levels and also because of the small percentage of the total phosphatide phosphorus which they represent when they are included in this calculation.

\section{DISCUSSION}

The data for the composition of the phosphatides of normal plasma presented here are in general agreement with the findings of Phillips (3),

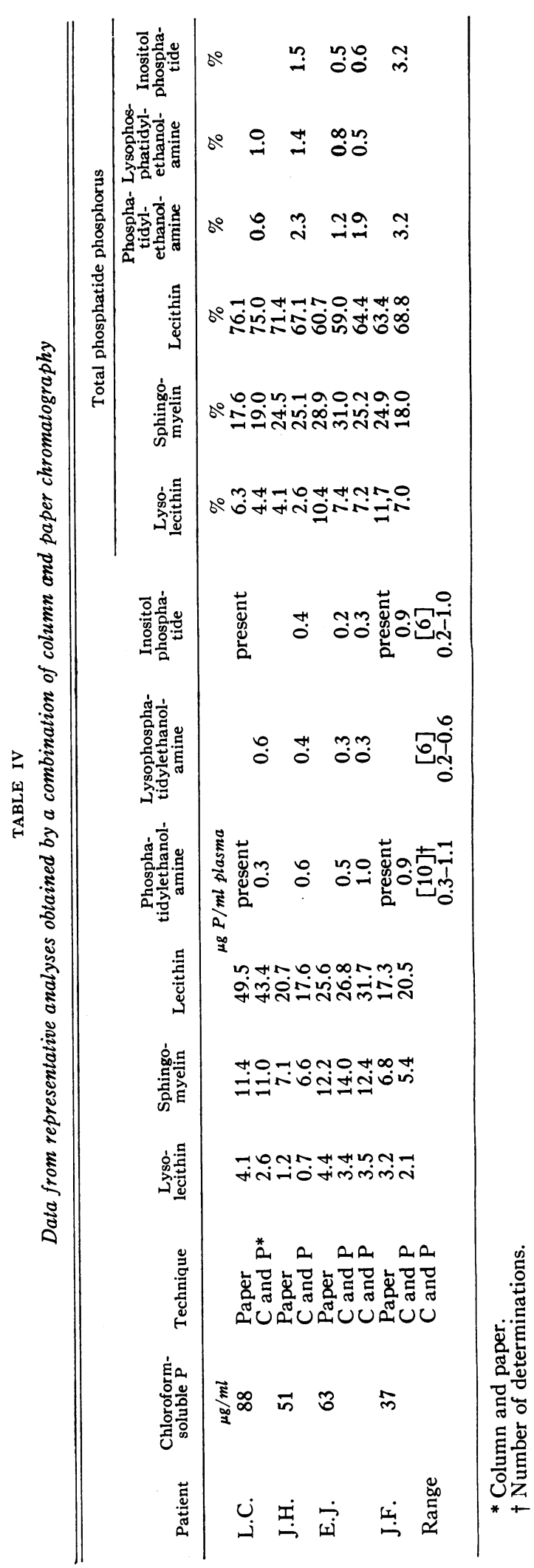


TABLE V

Normal fasting values for serum phosphatides calculated from the data of other investigators

\begin{tabular}{|c|c|c|c|c|c|c|c|c|c|}
\hline \multirow[b]{2}{*}{ Investigator } & \multirow[b]{2}{*}{$\begin{array}{c}\text { Samples } \\
\text { analyzed }\end{array}$} & & \multirow[b]{2}{*}{$\begin{array}{c}\text { Sphingo- } \\
\text { myelin }\end{array}$} & \multirow[b]{2}{*}{ Lecithin } & \multirow{2}{*}{$\underset{\substack{\text { Lyso- } \\
\text { lecithin }}}{\mathrm{t} i}$} & \multirow{2}{*}{$\begin{array}{l}\text { Phospha- } \\
\text { tidylethanol- } \\
\text { amine }\end{array}$} & \multicolumn{3}{|c|}{$\begin{array}{c}\text { Sum of average of } 3 \text { major } \\
\text { phosphatides }\end{array}$} \\
\hline & & & & & & & $\underset{\text { myelin }}{\text { Sphingo- }}$ & Lecithin & $\begin{array}{c}\text { Lyso- } \\
\text { lecithcin }\end{array}$ \\
\hline & & \multicolumn{5}{|c|}{$\mu g P / m l$ serume } & $\%$ & $\%$ & $\%$ \\
\hline \multirow{2}{*}{ Phillips (3) } & \multirow{2}{*}{7} & Range & ${ }_{26.7}^{14.9-}$ & $\begin{array}{l}61.1 \\
81.9\end{array}$ & ${ }^{6.1-}$ & ${ }^{4.2-}$ & & & \\
\hline & & Av. & 19.2 & 69.0 & $7.0^{\cdots}$ & $4.6^{\circ .4}$ & 20.2 & 72.3 & 7.4 \\
\hline \multirow{2}{*}{$\begin{array}{l}\text { Gjone, Berry and } \\
\text { Turner ( } 8)\end{array}$} & 8 & Range & \multicolumn{2}{|c|}{$\begin{array}{l}60.2- \\
109.5^{*}\end{array}$} & ${ }^{6.0} 10.7$ & $7^{3.4-} 9.8$ & & & \\
\hline & & Av. & $17.9 \dagger$ & $65.4 \dagger$ & 8.8 & $6.3^{.0}$ & 19.4 & 71.0 & 9.6 \\
\hline $\begin{array}{l}\text { Polonovski, Etienne } \\
\text { Paysant and Petit (11) }\end{array}$ & 6 & & & & & & \multicolumn{2}{|c|}{ 91.5* } & 8.5 \\
\hline \multirow[t]{2}{*}{$\begin{array}{l}\text { Marinetti, Albrecht, } \\
\text { Ford and Stotz (15) }\end{array}$} & \multirow[t]{2}{*}{$2 \ddagger$} & Range & $11.5-$ & ${ }^{36.0-} 41.5$ & $5.1-$ & $\begin{array}{l}0.51 \\
1.8\end{array}$ & & & \\
\hline & & Av. & 11.9 & 38.7 & 5.2 & 1.1 & 21.3 & 69.4 & 9.3 \\
\hline \multirow[t]{2}{*}{ Nelson and Freeman (9) } & \multirow[t]{2}{*}{$5 \S$} & Range & ${ }^{9.5-}$ & \multirow{2}{*}{\multicolumn{2}{|c|}{$\begin{array}{l}52.4- \\
77.6^{*} \\
65.2^{*}\end{array}$}} & $2.4-$ & & \multirow{2}{*}{\multicolumn{2}{|c|}{$78.7^{*}$}} \\
\hline & & Av. & 17.6 & & & 4.1 & 21.3 & & \\
\hline
\end{tabular}

* Eluted together.

† Calculated from the average ester bond/phosphorus ratio and from the average total phosphorus for the fraction containing lecithin and sphingomyelin.

$\ddagger$ Both samples were plasma.

$\$$ Calculated from the infrared measurements, assuming that phosphorus $=$ weight of phosphatide/25.

Marinetti, Albrecht, Ford and Stotz (15), and others $(8,11)$, but slight differences in the values for several components are apparent (Table V).

All workers confirm the presence of lysolecithin in normal plasma, with the exception of Nelson and Freeman (9); their failure to identify this component by silicic acid column chromatography and infrared spectroscopy is probably due to the qualitative similarity of the infrared spectrum of lysolecithin to that of lecithin, with which, in their system, the lysolecithin would probably be eluted (8). The quantitative estimation of lysolecithin in plasma has varied slightly among different investigators (Table V). The value obtained for lysolecithin in an analysis might possibly be influenced by four factors: 1 ) washing the lipid extract with water ; 2) incomplete elution of lysolecithin from the column; 3) contamination by another phosphatide; and 4) variability of the blank value in relation to the value for lysolecithin. Phillips washed his lipid extracts with water, and reported a loss of less than 1 per cent of the total phosphorus in the washing. If lysolecithin, being water-soluble as well as chloroform-soluble, were selectively washed out, it would be possible to lose up to 15 per cent of the lysolecithin from the extract. This factor alone cannot account for the lysolecithin values of Phillips being slightly lower than those of others, because higher values were reported by Gjone, Berry and Turner (8), who also washed their extracts and who reported no loss of lysolecithin because of this. Incomplete elution of lysolecithin from the column has occurred at times in our hands, and may account for the fact that the values for this phosphatide that we have obtained by a combined column and paper chromatographic analysis are lower than the values obtained by paper chromatographic analysis alone. The latter values agree with the data of Gjone and colleagues (8), who used the column technique of Hirsch and Ahrens (6). This technique is the most closely controlled of any devised to date, and it also is the only one that permits the elution of pure lysolecithin as a separate fraction. Contamination of lysolecithin by another phosphatide in paper chromatography may give a falsely high value. The lysolecithin spot from which phosphorus is eluted in our procedure is always overlapped to a small extent by the inositol phosphorus spot. However, most of the inositol phosphatide is excluded when the paper is cut, 
and since the total amount of inositol phosphatide present is not large (Table IV), the error introduced by this overlap must be quite small. Table I shows that the individual values obtained for the lysolecithin blank differ as much as 0.005 optical density units from the average 0.009 which is used to calculate the value of lysolecithin. This difference introduces the possibility of a 10 per cent error in our lysolecithin calculation. It is not known which of these factors, singly or in combination, is responsible for the small differences in lysolecithin concentration reported by various investigators, and it cannot be stated with certainty at the present time which absolute values for lysolecithin are the correct ones.

All figures for phosphatidylethanolamine are higher than ours, as shown in Tables IV and V. Other figures are derived from the phosphorus content or infrared spectrum of the cephalin fraction, while ours come from the phosphorus content of the phosphatidylethanolamine itself which has been determined by paper chromatography of the first column fraction and which comprises 55 per cent or less of the phosphorus in this fraction.

We have never found phosphatidylserine in plasma, nor have Phillips (3), Marinetti and coworkers (15), or Troup, Reed, Marinetti and Swisher (20); although Gjone and colleagues (8) and Nelson and Freeman (9) have reported finding traces of this constituent, and Phillips (3) has found serine in chromatograms of hydrolysates of lipid extracts of whole plasma. Phillips' paper chromatograms of extracts of whole plasma without hydrolysis, on the other hand, did not reveal serine or phosphatidylserine, indicating the possibility of the presence of very small amounts of other esters of serine, from which it could be liberated by hydrolysis.

The use of quantitative paper chromatography combined with column chromatography permits the identification and quantitation of the minor components-lysophosphatidylethanolamine, phosphatidylethanolamine, and inositol phosphatide. We think it is useful to present the data for the levels of plasma phosphatides in normal subjects in terms of the percentage of phosphorus in each constituent relative to the sum of the phosphorus in the three major constituents, because these data can be derived from a paper analysis alone. In investigations of clinical and experimental situations in which abnormalities of "cephalin" levels or metabolism might be looked for, more accurate data can be obtained by the combined use of column and paper chromatography.

Marinetti and colleagues (15) have found that as little as 80 per cent of the phosphorus in a total lipid extract may be accounted for as phosphatide, and we have found as little as 74 per cent in normal subjects (Table II) and even less in abnormal subjects (Table IV). We have assumed that this discrepancy represents carry-over by our extraction procedure of nonlipid phosphorus of unknown nature from the plasma, inasmuch as the lipid phosphorus of other tissues is accounted for quantitatively as phosphatide phosphorus by the same paper chromatographic methods. Marinetti, Witter and Stotz have demonstrated with $\mathrm{P}^{32}$-labeled orthophosphate and glycerophosphate that these water-soluble phosphates may be extracted with lipid, but that, after separation by paper chromatography, they will be removed to a great extent by the rhodamine staining procedure (21). Since all water-soluble phosphoruscontaining compounds (except lysolecithin) that have been tested remain at or near the origin on the paper chromatograms, those that might be present in plasma that are not removed by staining would not interfere with the quantitative analysis of the phosphatides $(15,21)$. Quantitative recovery of the phosphorus placed on a column usually occurs during the elution process. Contaminants that might be present in the lipid extract placed on the column would be delivered, at least partially, to the eluted phosphtide-containing fractions. To illustrate the distribution in the column fractions of the phosphorus that is not accounted for as phosphatide, Table III lists phosphatide phosphorus and the total phosphorus of each fraction expressed as a percentage.

\section{SUMMARY}

Plasma from normal fasting subjects was analyzed for the three major phosphatide constituents by means of quantitative paper chromatography. The values obtained are in agreement with published results obtained by the use of column chromatography, with certain minor exceptions which are discussed. The total chloroform-soluble phosphorus and absolute quantity of each constituent 
vary considerably, but the relative composition of the phosphaticles varies much less.

By means of combined column and paper analyses, all components can be quantitated, whereas by paper analysis alone, which requires one-third as much time, the three major components are quantitated, and the presence of the three other known components is confirmed.

\section{ACKNOWLEDGMENT}

The authors gratefully acknowledge the contribution of John Erbland, Department of Biochemistry, University of Rochester, who initially adapted the elution scheme of the column chromatographic technique (14) to the analysis of plasma lipids.

\section{REFERENCES}

1. Lea, C. H., Rhodes, D. N., and Stoll, R. D. Phospholipids. 3. On the chromatographic separation of glycerophospholipids. Biochem. J. 1955, 60, 353.

2. Phillips, G. B. The isolation of lysolecithin from human serum. Proc. nat. Acad. Sci. (Wash.) 1957, 43, 566.

3. Phillips, G. B. The isolation and quantitation of the principal phospholipid components of human serum using chromatography on silicic acid. Biochim. biophys. Acta 1958, 29, 594.

4. Phillips, G. B. Lipid composition of human serum lipoprotein fraction with density greater than 1.210. Proc. Soc. exp. Biol. (N. Y.) 1959, 100, 19.

5. Phillips, G. B. The phospholipid composition of human serum lipoprotein fractions separated by ultracentrifugation. J. clin. Invest. 1959, 38, 489.

6. Hirsch, J., and Ahrens, E. H., Jr. The separation of complex lipide mixtures by the use of silicic acid chromatography. J. biol. Chem. 1958, 233, 311.

7. Gjone, E., Berry, J. F., and Turner, D. A. Isolation and identification of lysolecithin from lipid extracts of normal human serum. Biochim. biophys. Acta 1959, 34, 288.

8. Gjone, E., Berry, J. F., and Turner, D. A. The isolation and identification of lysolecithin from lipid extracts of normal human serum. J. Lip. Res. $1959,1,66$.
9. Nelson, G. J., and Freeman, N. K. Serum phospholipide analysis by chromatography and infrared spectrophotometry. J. biol. Chem. 1959, 234, 1375.

10. Nelson, G. J., and Freeman, N. K. The phospholipid and phospholipid fatty acid composition of human serum lipoprotein fractions. J. biol. Chem. 1960, 235, 578.

11. Polonovski, J., Etienne, J., Paysant, M., and Petit, M. Fractionnement chromatographique des phospholipides plasmatiques. Ann. Biol. clin. 1959, 17, 186.

12. Waterhouse, C., and Marinetti, G., Tracer studies of plasma lipids in human subjects (abstract). J. clin. Invest. 1959, 38, 1053.

13. Waterhouse, C., and Marinetti, G. V. The incorporation of $\mathrm{C}^{14}$-labeled fatty acids into the lipids of human plasma. Trans. Ass. Amer. Phycns 1960, 73. In press.

14. Marinetti, G. V., Erbland, J., and Kochen, J. Quantitative chromatography of phosphatides. Fed. Proc. 1957, 16, 837.

15. Marinetti, G. V., Albrecht, M., Ford, T., and Stotz, E. Analysis of human plasma phosphatides by paper chromatography. Biochim. biophys. Acta 1959, 36, 4.

16. Harris, W. D., and Popat, P. Determination of the phosphorus content of lipides. J. Amer. Oil Chemists Soc. 1954, 31, 124.

17. Marinetti, G. V., Erbland, J., Albrecht, M., and Stotz, E. The application of chromatographic methods to study the incorporation of ${ }^{32} \mathrm{P}$-labeled orthophosphate into the phosphatides of rat liver homogenates. Biochim. biophys. Acta 1957, 25, 585.

18. Chen, P. S., Jr., Toribara, T. Y., and Warner, H. Microdetermination of phosphorus. Analyt. Chem. 1956, 28, 1756.

19. Dawson, R. M. C. The measurement of ${ }^{32} \mathrm{P}$-labelling of individual kephalins and lecithin in a small sample of tissue. Biochim. biophys. Acta 1954, 14, 374.

20. Troup, S. B., Reed, C. F., Marinetti, G. V., and Swisher, S. N. Thromboplastic factors in platelets and red blood cells: Observations on their chemical nature and function in in vitro coagulation. J. clin. Invest. 1960, 39, 342.

21. Marinetti, G. V., Witter, R. F., and Stotz, E. The incorporation in vivo of $\mathrm{P}^{32}$-labeled orthophosphate into individual phosphatides of rat tissues. J. biol. Chem. 1957, 226, 475. 